\title{
EFFECT OF ANTIOXIDANTS ON THE OXIDATIVE STABILITY OF JATROPHA BIODIESEL
}

\section{NATESH KAPILAN}

R\&D Centre, Department of Mechanical Engineering, Nagarajuna College of Engineering and Technology, Devanahalli, Bangalore - 562 110, India, Tel.: +91 9845418874, Fax: +91 080 27645990, E-mail: kapil_krecmech@yahoo.com

\section{CHANDRA SEKAR BIRDAR}

Department of Biotechnology, Nagarajuna College of Engineering and Technology, Devanahalli, Bangalore - 562 110, India Tel.: +91080 27645993, Fax: +9108027645990

\section{SHRNUTÍ}

Řekne-li se obnovitelné palivo, napadne nás okamžitě bionafta jako prímá náhrada nafty. Vlastnosti bionafty jsou podobné naftě, avšak chemické složení bionafty vede $\mathrm{k}$ její oxidaci během skladování. $\mathrm{S}$ postupující oxidací významně degradují vlastnosti bionafty. Pokud dojde $k$ velké změně vlastností, tak bionafta už nemusí odpovídat dané specifikaci a může dojít i k poškození vstřikovacího systému. Přidání vhodných antioxidantů může výrazně zvýšit stabilitu paliva. V Indii je bionafta vyráběna z nejedlých plodů stromu Jatropha, který má velký potenciál pro výrobu bionafty. Tento článek popisuje vlastnosti bionafty vyrobené z metylesteru oleje stromu Jatropha. Byla analyzována prítomnost mastných kyselin v bionaftě Jatropha. Byly provedeny experimentální studie vedoucí ke zvýšení stability tohoto paliva.

KLÍĊOVÁ SLOVA: ALTERNATIVNÍ PALIVA, BIO-NAFTA JATROPHA, VLASTNOSTI, STABILITA, ANTIOXIDANTY

\section{ABSTRACT}

Among the renewable fuels, biodiesel is considered immediate direct substitute for the fossil diesel in internal combustion engines. The fuel properties of biodiesel are similar to the fossil fuel, but its chemical nature leads to its oxidization during storage. Hence, the fuel properties of biodiesel degrade due to oxidation and the properties of the biodiesel changes significantly. If the property values change significantly, then the biodiesel may not satisfy the biodiesel fuel specifications and this can affect the fuel injection components. However, the addition of a suitable antioxidant will increase the stability or induction period of the biodiesel. In India, biodiesel is produced from non-edible Jatropha oil which has considerable potential for biodiesel production. In this work biodiesel was produced from non-edible Jatropha oil and its important fuel properties were determined. Also, the fatty acid composition analysis of the Jatropha biodiesel was carried out to determine the presence of unsaturated fatty acids. An experimental study was performed to increase the stability or induction period of the Jatropha biodiesel.

KEYWORDS: ALTERNATIVE FUEL, JATROPHA BIODIESEL, PROPERTIES, STABILITY, ANTIOXIDANT

\section{INTRODUCTION}

Biodiesel is a biofuel produced from vegetable oils and fats. It is produced by a chemical process known as transesterification whereby either ethanol or methanol is reacted, in the presence of a catalyst, with an oil or fat to produce an ester and glycerol. This process involves a reaction of the oil with an alcohol to remove the glycerin, which is a by-product of biodiesel production $[1,2]$.

In recent years, biodiesel has been used as a renewable and commercial substitute for the fossil diesel due to its properties which are close to that of fossil diesel [3]. Also, biodiesel is popular in under developed and developing countries, due to improvement in the local employment, savings in foreign exchange etc. When biodiesel is used as fuel in a diesel engine, considerable reduction in the engine emissions, such as hydrocarbon, particulate and carbon monoxide emissions, have been reported in literature [4]. Biodiesel is considered a renewable substitute for fossil diesel, but its poor oxidative stability is an obstacle to its complete acceptance by diesel engine manufacturers. 
India imports more than $65 \%$ of crude oil from other countries to meet its energy requirements and the demand for diesel and gasoline increases every year [5]. It has been reported in literature that the demand for diesel was 66.90 Mt in the year 2011-2012. Hence, as part of steps taken by the Government of India biodiesel and alcohol are being considered as a renewable substitute for the petroleum fuels [6]. In India, biodiesel is mainly produced from non-edible oils as there is demand for the edible oils [7].

Many vegetable oils contain a significant amount of fatty acids with double bonds, which results in their biodiesel instability. Sediment and gum formation and fuel darkening takes place due to oxidation, and this may cause filter plugging, injector fouling, and depositions in the engine combustion chambers and fuel injection components [8]. Abderrahim et al [9] studied the long storage stability of biodiesel prepared from vegetable oils such as high oleic sunflower oil, high and low erucic Brassica carinata oil and used frying oil. Their results showed that the acid value, density and viscosity of the biodiesel increases with increase in storage time. McCormick et al. [10] examined the factors impacting the stability of biodiesel samples collected as part of a 2004 nationwide fuel quality survey in the United States. They noticed that the polyunsaturated content has the largest impact on both increasing insoluble formation and reducing the induction time.

From the literature it is clear that the rate of oxidation of fatty compounds depends on the number of double bonds and their position. Linoleic acid is more susceptible to oxidation because it contains double bonds. In general, the fatty acids with conjugated double bonds are even more susceptible to oxidation. Addition of antioxidants to the biodiesel will increase the oxidation stability; according to the European biodiesel standard, the minimum requirement for oxidation stability in terms of induction period is 6 hours by the Rancimat method.

Abdul [11] reported that the oxidized biodiesel affects both diesel engine performance and emissions. Haiying et al. [12] reported that different types of biodiesel have

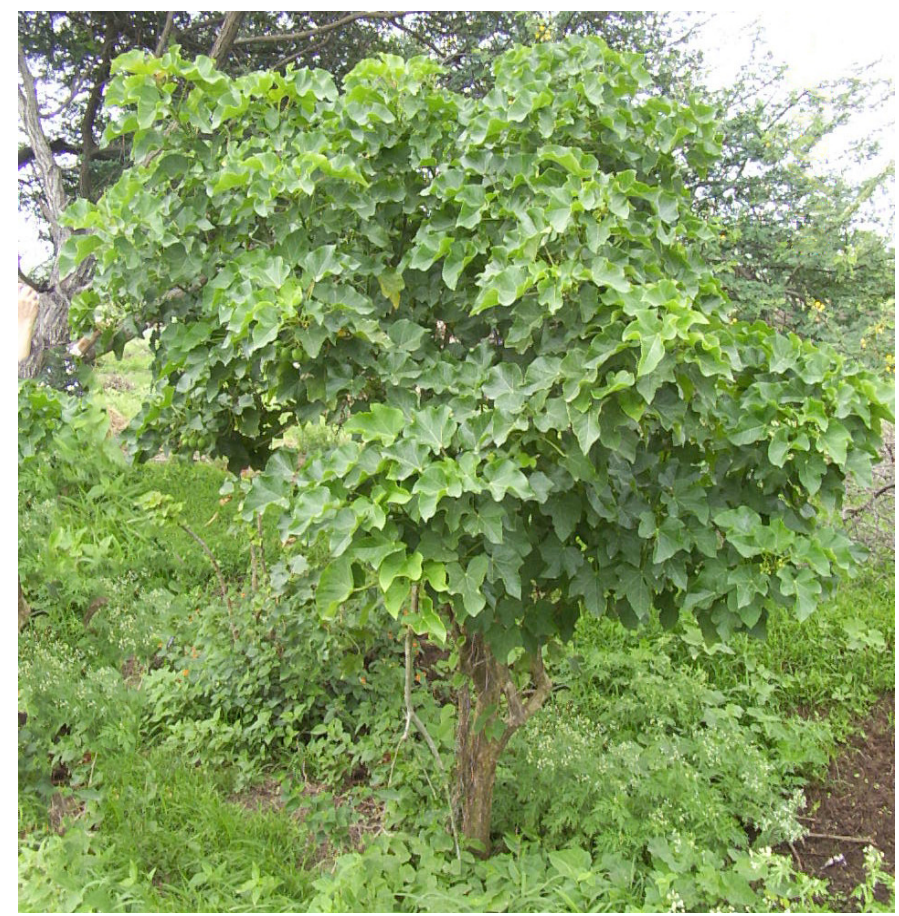

FIGURE 1: Jatropha

OBRÁZEK 1: Strom Jatropha

different natural levels of oxidative stability, indicating that natural antioxidants play a significant role in determining oxidative stability. Several researchers [13] investigated the effectiveness of various natural and synthetic antioxidants and reported that these antioxidants improve the oxidative stability of biodiesel at varying concentrations between 250 and $1000 \mathrm{ppm}$.

Researchers [14] used several antioxidants of biodiesel for their work. The results showed that propyl gallate was the best antioxidant for the Jatropha biodiesel at concentrations of 50, 150, 250, 350, 500, 650 and 750 ppm, which improved the induction time. Siddharth et al. [15] found that the influence of metal was detrimental to thermal and oxidation stability. Even small concentrations of metal contaminants such as copper exhibit nearly the same influence on oxidation stability as large amounts.
Butylated Hydroxyanisole (BHA)<smiles>COc1ccc(O)c(C(C)(C)C)c1</smiles>

Butylated Hydroxy Toluene (BHT)<smiles>Cc1cc(C)c(O)c(C)c1</smiles>

Propyl Gallate (PG)<smiles>CCCCCOC(=O)c1cc(O)c(O)c(O)c1</smiles>

OBRÁZEK 2: Antioxidanty 
Jatropha is a medium sized tree that generally attains a height of about 8 meters and is shown in Figure 1. It is a tropical plant that can be grown in low to high rainfall areas. In India, Jatropha oil is preferred for biodiesel production as this is non-edible and has considerable potential for the production of biodiesel. Jatropha oil is a thick yellow-orange oil and is extracted from seeds. The oil is non-edible and hence it is used as a fuel for cooking and lamps in rural India [16].

The toxicity of Jatropha curcas to animals and humans is due to the presence of substances such as phorbol esters, lectin etc. Rakshit et al [17] used alkali and heat treatments to deactivate the toxic components such as phorbol ester and lectin present in the Jatropha meal. They are carrying out further studies for the complete detoxification of Jatropha curcas meal for use in livestock feed. Harinder et al [18] reported that the local communities in Mexico consume Jatropha platyphylla seeds after roasting, because heattreated Jatropha platyphylla kernel meal is free of trypsin inhibitor and lectin activity.

\section{MATERIALS AND METHODOLOGY}

In this work, biodiesel was produced from non-edible Jatropha oil by a two-step transesterification process. A gas chromatography $(\mathrm{GC})$ analysis was carried out to determine the fatty acid composition of the Jatropha biodiesel. The effect of antioxidants on the stability of the biodiesel was assessed using the Rancimat test method. The commercial anti-oxidants butylated hydroxyanisole (BHA), butyl-4hydroxytoluene (BHT) and propyl gallate (PG) were used as antioxidants in this work and their chemical structure is shown in Figure 2. These antioxidants were added to the biodiesel at concentrations of 250, 500 and $750 \mathrm{ppm}$.

\section{I BIODIESEL PRODUCTION}

The biodiesel was produced from Jatropha oil by a two-step transesterification method. The acid value of the biodiesel was reduced by esterification in the first step. In the second step, the pre-treated Jatropha oil of first step was converted into biodiesel using alkaline catalyzed transesterification. Figure 3 shows the experimental setup used for the biodiesel production.

The Jatropha oil is non-edible oil and has a higher acid value. The acid value of the Jatropha oil was reduced to below $1 \mathrm{mg}$ of $\mathrm{KOH} / \mathrm{g}$ of oil by an etherification process using $\mathrm{H}_{2} \mathrm{SO}_{4}$ as the catalyst. This reaction was carried out at a methanol to oil ratio of $6: 1$, and at a reaction temperature of $60^{\circ} \mathrm{C}$. After this reaction, the products were shifted to a separating funnel and the bottom layer, pre-treated Jatropha oil, was removed and was used in the second step transesterification. In the second step, base catalyst, potassium hydroxide pellets

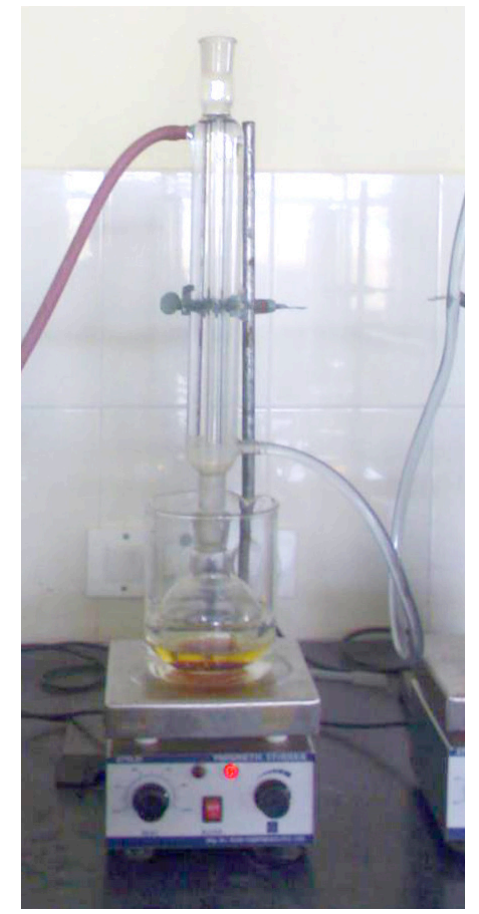

FIGURE 3: Biodiesel Production Setup OBRÁZEK 3: Zařízení pro výrobu bionafty

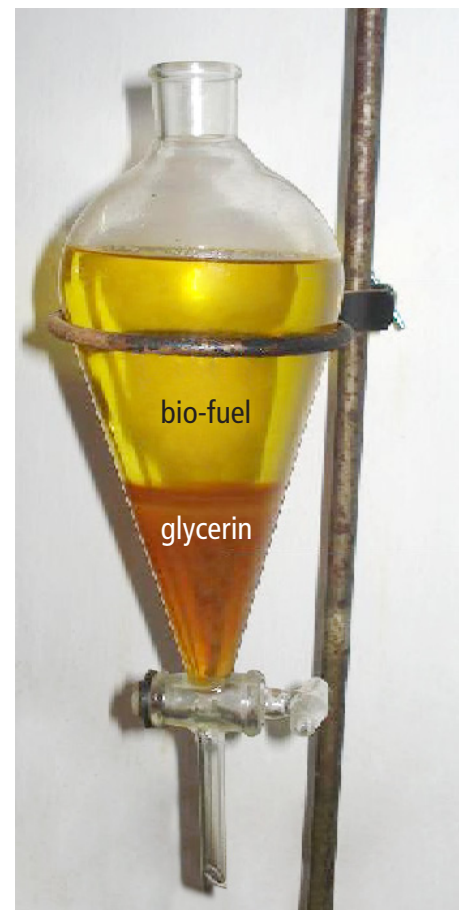

FIGURE 4: Products of transesterification OBRÁZEK 4: Produkty transesterifikace

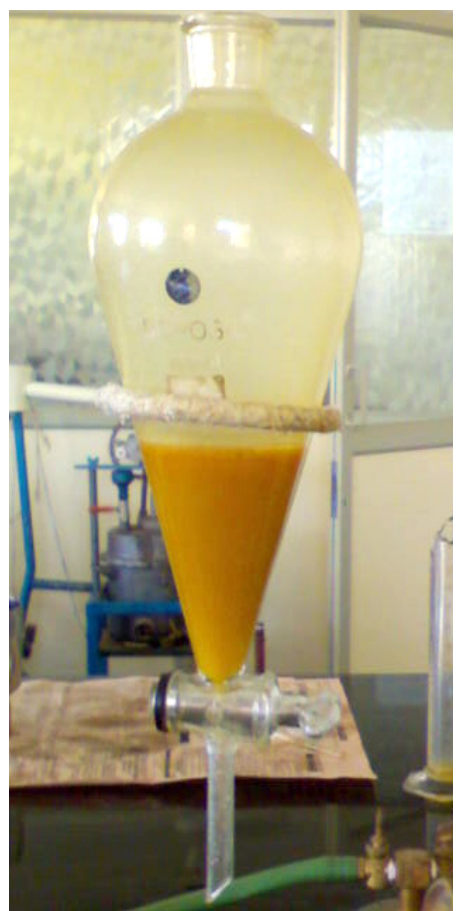

FIGURE 5: Biodiesel during water-wash OBRÁZEK 5: Bionafta během čištění 
TABLE 1: Fatty Acid Composition

TABULKA 1: Skladba mastných kyselin

\begin{tabular}{lcc|} 
& \multicolumn{2}{c}{ Content \% } \\
\cline { 2 - 3 } Fatty Acids & Experiment & Literature [21] \\
\hline Myristic Acid & 0.06 & 0.38 \\
\hline Palmitic Acid & 14.27 & 16.0 \\
\hline Stearic Acid & 8.07 & 6 to 7 \\
\hline Oleic Acid & 38.27 & 42 to 43.5 \\
\hline Linoleic Acid & 34.54 & 33 to 34.4 \\
\hline Linolenic Acid & 0.06 & $>0.80$ \\
\hline Arachidonic Acid & 0.10 & 0.20 \\
\hline Behenic Acid & 0.15 & \\
\hline
\end{tabular}

TABLE 2: Properties of Jatropha Biodiesel TABULKA 2: Vlastnosti bionafty Jatropha

\begin{tabular}{|llccc|}
\hline S.N $N^{\circ}$ Property & ASTM D6751 & EN 14214 & $\begin{array}{c}\text { Jatropha } \\
\text { Biodiesel }\end{array}$ \\
\hline 1 & Flash Point $\left({ }^{\circ} \mathrm{C}\right)$ & $>130$ & $>120$ & 140 \\
\hline 2 & Density at $15^{\circ} \mathrm{C}\left(\mathrm{kg} / \mathrm{m}^{3}\right)$ & & 860 to 900 & 889 \\
\hline 3 & Viscosity at $40^{\circ} \mathrm{C}\left(\mathrm{mm}^{2} / \mathrm{s}\right)$ & 1.9 to 6 & 3.5 to 5.0 & 4.1 \\
\hline 4 & Cloud Point $\left({ }^{\circ} \mathrm{C}\right)$ & & & 4 \\
\hline 5 & Pour Point $\left({ }^{\circ} \mathrm{C}\right)$ & & & 3 \\
\hline 6 & Calorific Value $(\mathrm{MJ} / \mathrm{kg})$ & & & 38.4 \\
\hline 7 & Copper Corrosion Test & $>\mathrm{N}^{\circ} .3$ & Class 1 & 1 \\
\hline 8 & Ash Content $(\% \mathrm{wt})$ & $<0.02$ & $<0.02$ & 0.01 \\
\hline 9 & Acid Value $(\mathrm{mg} \mathrm{KOH} \mathrm{g)}$ & $<0.50$ & $<0.5$ & 0.4 \\
\hline
\end{tabular}

( $1 \%$ by weight of oil), was dissolved in the methanol and this solution was transferred to the round bottom flask containing pre-treated oil. The reaction conditions maintained in the second step are a molar ratio of methanol to oil of $6: 1$, reaction temperature $60^{\circ} \mathrm{C}$ and the reaction time of 90 minutes. The reactants were heated uniformly using a water bath and the reactants were mixed using a magnetic stirrer. After the transesterification reaction, the mixture was heated above $70^{\circ} \mathrm{C}$ to remove the excess methanol and then the products of transesterification were taken out and poured into the separating funnel. The products of transesterification were allowed to settle by gravity in a separating funnel and two distinct layers were formed, as shown in Figure 4. The top layer, crude biodiesel, was separated and then the crude biodiesel was washed with warm distilled water to remove the excess catalyst and impurities present in the biodiesel.
Figure 5 shows the biodiesel during the water wash. After water wash, the biodiesel was separated and heated to $100^{\circ} \mathrm{C}$ for 10 minutes to remove the moisture.

\section{RESULTS AND DISCUSSIONS}

The biodiesel was successfully produced from Jatropha oil by a two-step transesterification and the biodiesel yield obtained was $91.5 \%$. In literature, it is reported that the biodiesel yields obtained by conventional two step [19], microwave [20] and ultrasonic [21] assisted transesterification are $90.1 \%, 89.7 \%$ and $96.4 \%$ respectively. The biodiesel sample was tested using gas chromatography to determine its fatty acid composition. Table 1 shows the fatty acid composition of the Jatropha biodiesel, and it is observed that the Jatropha biodiesel contains increased amounts of unsaturated fatty acids. These unsaturated fatty acids reduce the induction period of the Jatropha biodiesel. The properties of the Jatropha oil biodiesel are determined as per ASTM and are shown in Table 2. From the table it can be seen that the properties of the Jatropha biodiesel are close to diesel and satisfy the biodiesel fuel standards. Also, the composition of the Jatropha biodiesel is similar to the data published in literature.

Figure 6 shows the schematic of the biodiesel oxidation stability apparatus which works as per the Rancimat method. In this method oxidation is induced on the biodiesel by passing air at a rate of $10 \mathrm{l} / \mathrm{h}$ through the biodiesel sample which is kept in the heating element. The heating temperature was maintained constant at $110^{\circ} \mathrm{C}$. The biodiesel vapours produced by the oxidation process along with the air enter the flask containing distilled water. An electrode is provided in the flask to measure the conductivity of the distilled water. When the conductivity readings are recorded continuously, an oxidation curve is obtained whose point of inflection is known as the induction, which provides a good characteristic value for the oxidation stability.

The induction period (IP) of the Jatropha biodiesel with different antioxidants at concentrations of $0,250,500$ and $750 \mathrm{ppm}$ is shown in Figure 7. From the Figure it can be seen that the induction period or stability of the Jatropha biodiesel increases with increased concentration of antioxidants. From the Figure it can be seen that propyl gallate (PG) is better than other antioxidants and also significantly improves the oxidation stability of the Jatropha biodiesel. The antioxidant BHT is better than the BHA for the Jatropha biodiesel. The propyl gallate concentration of $750 \mathrm{ppm}$ results in an induction period of more than 6 hours. Hence, for the Jatropha biodiesel, propyl gallate is the better antioxidant. 


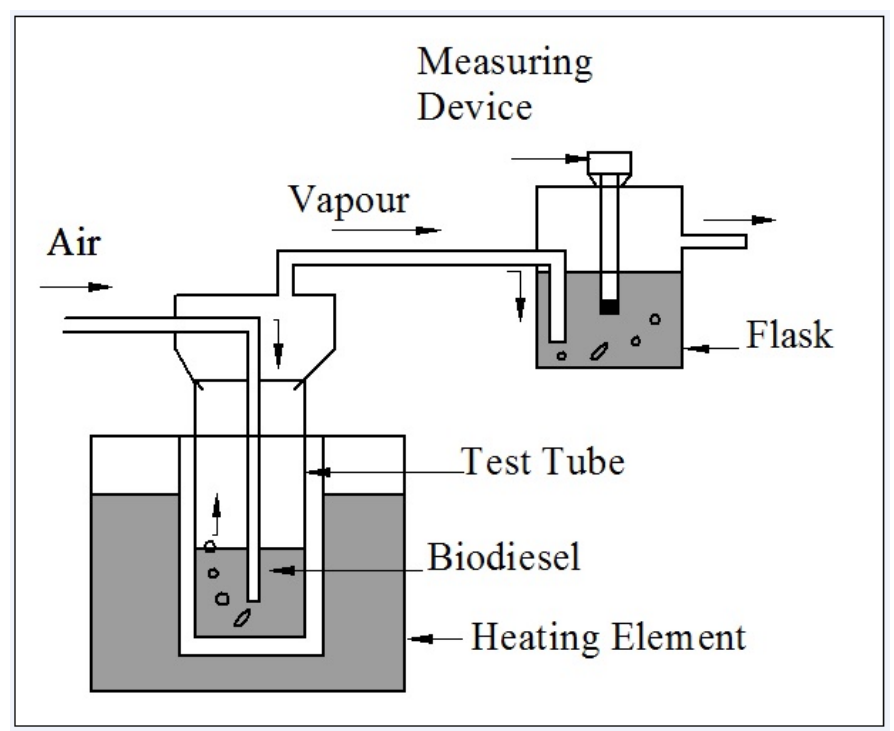

FIGURE 6: Effect of antioxidants on Induction Period OBRÁZEK 6: Vliv jednotlivých antioxidantů na indukční dobu

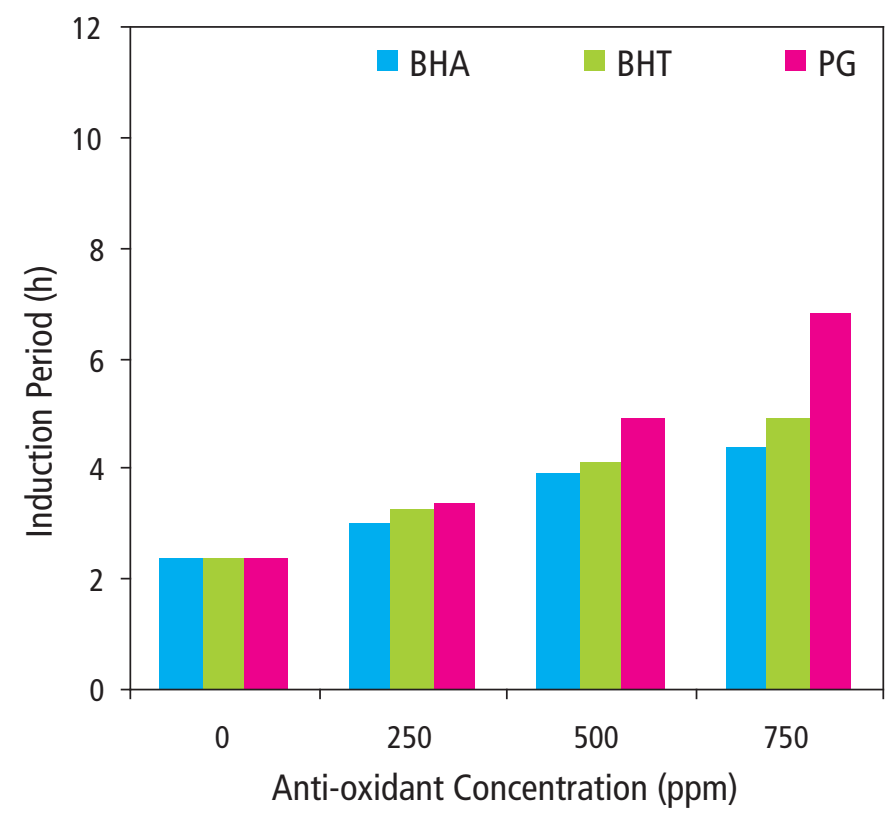

FIGURE 7: Effect of antioxidants on Induction Period OBRÁZEK 7: Vliv jednotlivých antioxidantů na indukční dobu

\section{CONCLUSION}

In this work, biodiesel was produced from Jatropha oil by a two-step transesterification process. From the property analysis it is observed that the Jatropha biodiesel satisfies the biodiesel fuel standards. The gas chromatography spectra shows that the Jatropha oil contains more than $50 \%$ unsaturated fatty acids, which makes them prone to oxidation and reduces the induction period. The induction period of the Jatropha biodiesel was determined using the Rancimat test method. From the Rancimat test it is observed that the antioxidant propyl gallate $(P G)$ at a concentration of $750 \mathrm{ppm}$ results in better stability as compared to other antioxidants.

\section{ACKNOWLEDGEMENTS}

The authors wish to express their thanks to VTU, Belgaum, India, for financially supporting this research work (Grant No. VTU/Aca./2009-10/A-9/11583, 2009). Authors also thank Bangalore Test House, India, for GC analysis of biodiesel samples.

\section{REFERENCES}

[1] Meher L.C., Vidya Sagar D, Naik S.N. (2006), Technical aspects of biodiesel production by transesterification - a review. In: Renewable and Sustainable Energy Reviews, Vol. 10, Issue 3, pp. 248-268.

[2] Abbaszaadeh A., Ghobadian B., Omidkhah M.R., Najafi G. (2012), Current biodiesel production technologies: A comparative review. In: Energy Conversion and Management, Vol. 63, pp. 138-148.

[3] Atabani A.E., Silitonga A.S., Badruddin I.A., Mahlia T.M., Masjuki H.H., Mekhilef S. (2012). A comprehensive review on biodiesel as an alternative energy resource and its characteristics. In: Renewable and Sustainable Energy Reviews, Vol. 16, Issue 4, pp. 2070-2093.

[4] Xue J., Grift T. E., Hansen A. C. (2011). Effect of biodiesel on engine performances and emissions. In: Renewable and Sustainable Energy Reviews, Vol. 15, pp. 10981116.

[5] http://www.eia.doe.gov/oiaf/ieo,http://www.eia.doe.gov/ emeu/cabs/India/Oil.html

[6] Subramanian K.A, Singal S.K, Mukesh S. and Sudhir S. (2005). Utilization of liquid biofuels in automotive diesel engines - An Indian perspective. In: Journal of Biomass and Bioenergy, Vol. 29, pp. $65-72$.

[7] Kumar A., Sharma S. (2011). Potential non-edible oil resources as biodiesel feedstock: An Indian perspective. In: Renewable and Sustainable Energy Reviews, Vol. 15, Issue 4, pp. $1791-1800$.

[8] Abdul M., Gerpen van J.H. (2001). The effect of biodiesel oxidation on engine performance and emissions. In: Biomass and Bioenergy, Vol. 20, pp. 317-325.

[9] Bouaid A., Martinez M. and Aracil J. (2007). Long storage stability of biodiesel from vegetable and used frying oils. In: Fuel, Vol. 86, No 16, pp. 2596-2602.

[10]McCormick R.L., Ratcliff M., Moens L. and Lawrence R. (2007). Several factors affecting the stability of biodiesel in standard accelerated tests. In: Fuel Processing Technology, Vol. 88, Issue 7, pp. 651-657. 
[11]Monyem A., Gerpen van J. H. (2001). The effect of biodiesel oxidation on engine performance and emissions. In:Biomass and Bioenergy, Vol. 20, pp. 317-325.

[12]Tang H., Anfeng E., Wang E., Steven E., Salley O., Simon N. K.Y. (2008). The Effect of Natural and Synthetic Antioxidants on the Oxidative Stability of Biodiesel. In: Journal of American Oil Chemists Society, Vol. 85, pp. $373-382$.

[13] Improved oxidative stability of biodiesel fuels, Report No: MIOH UTCAF4p2-5 2011, Michigan Ohio University Transportation Center project supported by the U.S.

[14]Chaithongdee D., Chutmanop J. and Srinophakun P. (2010). Effect of Antioxidants and Additives on the Oxidation Stability of Jatropha Biodiesel. In: Kasetsart Journal of Natural Science, Vol. 44, pp. $243-250$.

[15]Jain S., Sharma M.P. (2011). Oxidation and thermal behavior of Jatropha curcas biodiesel influenced by antioxidants and metal contaminants. In: International Journal of Engineering, Science and Technology, Vol. 3, No. 4 , pp. $65-75$.

[16]http://www.svlele.com/karanj.htm

[17]Rakshit K.D., Darukeshwara J., Raj K. R., Narasimhamurthy K., Saibaba P., Bhagya S. (2008). Toxicity studies of detoxified Jatropha meal (Jatropha curcas) in rats. In: Food and Chemical Toxicology, Vol. 46, Issue 12, pp. $3621-3625$.

[18]Makkar H. P. S., Kumar V., Oyeleye O. O., Akinleye A. O., Angulo-Escalante M.A., Becker K. (2011). Jatropha platyphylla, a new non-toxic Jatropha species: Physical properties and chemical constituents including toxic and antinutritional factors of seeds. In: Food Chemistry, Vol. 125, Issue 1, pp. 63-71.

[19] Jain S., Sharma M.P. (2010). Biodiesel production from Jatropha curcas oil. In: Renewable and Sustainable Energy Reviews, Vol. 14, Issue 9, pp. 3140-3147.

[20]Yaakob Z., Ong B. H., Kumar M.N.S.; Kamarudin S. K. (2009). Microwave-assisted transesterification of jatropha and waste frying palm oil. In: International Journal of Sustainable Energy, Vol. 28, Issue 4, pp. 195-201.

[21]Deng X., Fang Z., Liu Y. (2010). Ultrasonic transesterification of Jatropha curcas L. oil to biodiesel by a two-step proces. In: Energy Conversion and Management, Vol. 51, Issue 12, pp. 2802-2807. 